\title{
アルコール負荷による眼球運動特性の 要化について
}

\section{○加藤象二郎閂尾孝是長沢 有恒 (航空医学実験隊)}

【目的】：本実驗は航空場面における操㮆者 の代表的な梘覚情報処理内容を眼球運動特性 の側面からとらえ、アルコールによるこの種 処理や眼球運動への影響を見ようとしたもの である。代表的な視覚情報処理内容として は、時的な視走查反応、事象比較に誘発さ れる視走查反応、そして入手情報の一次ない し数次处理結果に誘発される視走查反応であ る。実驗条件は、Rayner (1978) やVaughan( 1982）による随意的な眼球運動潜時は入力情 報の処理時間に対応するという桔果を、また Klein(1972) による各種薬物のパフォーマン スへの影響を定量的に評洒するためには、ア ルコールを基準物筫とすべきことを提唱し、 その有奻性の检証結果を配虑して選択した。

【方法】： 当隊に所属する煡常な男子(24 41蔵）6名を被駼者とした。視力は繑正視力 者を含め 0.7 1.5 の範囲の者、体重は54 7 $2 \mathrm{Kg}$ の者である。刺游提示装冝は、中央固視 点用赤色LED $(\phi=3.5 \mathrm{~mm})$ を中心に7seg.LED（ 赤色）2 個を並列設置し、かつ中央固視点 (C F) から左右各25度の視角位置に周辺固視点 (P F) 用LED 各 1 個を取りつけた黒色ボードを被 倹者の顔前60c西の距離に設置した。被駼者の 顏面は顔面固定具により刺湤提示装置との相 対位亚関保を保持するように配虑した。眼

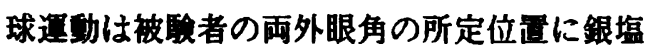
化銀小型生体電極を貼り、直流高感度アンプ
及び生体用ボリグラフ(NK 製) を介すEOG 法 により導出し、MT収録した。刺激発生装冝 は龱1の刺湤提示シークエンスを管理しえる 当隊医用電子研究室製作のものを使用した。

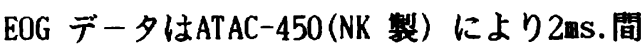
隔でAD変换し、分析した。被䮲者には並列 設宣した7seg.LED 2 個のいずれか片側に数字 1 析を提示し、点灯側のPFへできるだけ素早 く固視移動させるSR条件、2 個の数字を提示 し数字の大小比較により大きい数字の側のPF へ素早く固視移動させるCR条件、そして2個 の数字の加算結果の奇 · 偶数を判断し、左右 いずれかのPFへ秦早く固視移動させるAR条件 、の3 種の反応条件を負荷した。提示数字お よび3 種反応条件の実施順はランダムとした 。ISI はSR条件で10秒、CR及びAR条件で20秒 とし、各条件10試行を各5回、3日間、計45 0 試行を実施、4 日目をアルコール負荷実駼 日とした。アルコール負荷量は被䮲者体重 $1 \mathrm{Kg}$ 当り純アルコール換算で1.0m1 とした。 飲酒条件として、被联者には実匴前夜の飲酒 と当日の朝食を禁し、、アルコールの体内吸収 勾配に影響する要因の減少を图った。飲酒時 間は1hとし、飲酒完了後30分、90分、150 分 、210 分時に上記 3 種反応条件下で各10試行 させた。アルコール血中瀑度 (BAC) は各セッ ション開始時に被駺者の耳架より $20 \mu \ell$ を探 血し、ガスクロマトグラフィにより分析した。 
【結果と考察】：（1）アルコール血中濃 度 : BAC は飲酒完了後30分時でピーク值 $(0.8$

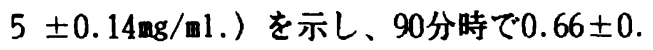

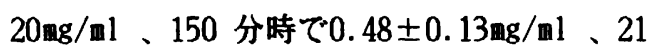
0 分時ではピーク值の半減を示す $0.40 \pm 0.09$ $\mathrm{mg} / \mathrm{ml}$ であった。（2）眼球運動反応潜時： 糛制実駺時 (CNT) の3 種反応条件別の平均潜 時は累積試行数の増加にともない潜時の減少 (練習奻果) が見られ、反応条件の被雑なも のほど潜時の娍少奻果が著しい（図2）。困 中のAR1, AR2 は加草結果が 1 栴と 2 析の場合 に各々対応している。提示刺湤数字に対する 処理内容の被雑さが增すにつれ、各反応条件 間の潜時平均值は有意に增加し、この平均值 の差はCNT 時及びアルコール負荷実湌時 (ALC )のいずれのセッションにおいてもはぼ一定 である。またCNT での141 150 試行セッショ ン時の 3 種反応条件の潜時平均值とALC30 分 時の潜時平均值とを比較すると、後者におい て潜時增加がみられたが、統計的有意差はAR 1 とAR2 にのみ得られた。

( 3 ）眼球運動

速度 : CNT 及びALC の各セッション内におい て、平均眼球通動速度 (EMV) は3種反応条件 別の相逜はほとんど見られず、はほ一定の值 を示した（図3）。しかし、CNT とALC との 间にはアルコールの影㳻による有意な $(\mathrm{P}<0.0$ 1)速度低下（SRで-40deg/sec、CRで-50deg/s ec、ARで-80deg/sec) みられ、低下事は全体 平均で20.1\%であった。これらの結果から以 下の点が示唆された：（i ） CNT でのEMV 変 化のないことは反応潜時でみられた練習奻果 の要因はEMVに影繁しないこと、(ii)本実臨 で取りあげた 3 種反応条件（処理内容の複雑 さ）はEMVに影脈しないこと、（ iii）ALC 各 セッションのEMV が一定であることから、こ の期間内のBAC 低下度 $(0.85 \rightarrow 0.40 \mathrm{mg} / \mathrm{ml})$ は EMV の回復には結びつかないこと、等である。

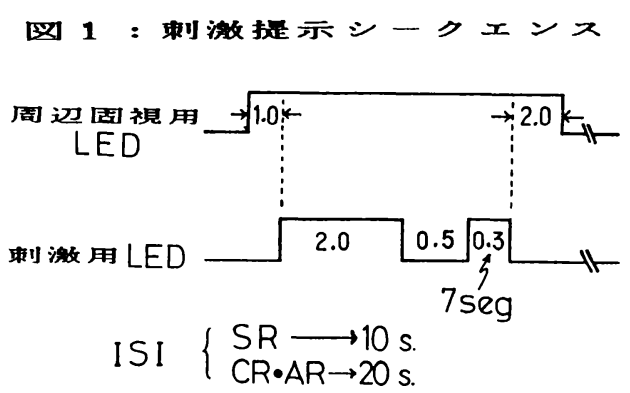

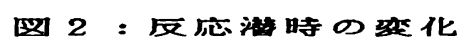

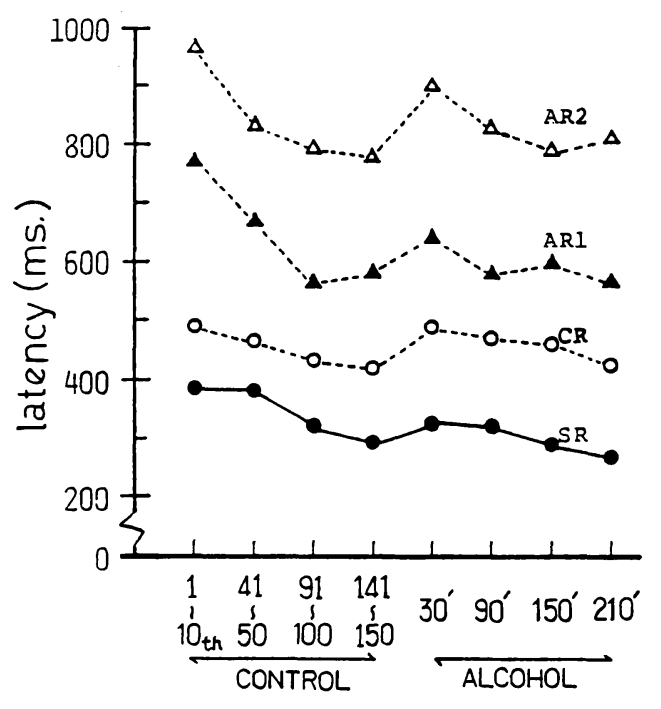

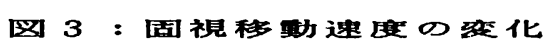

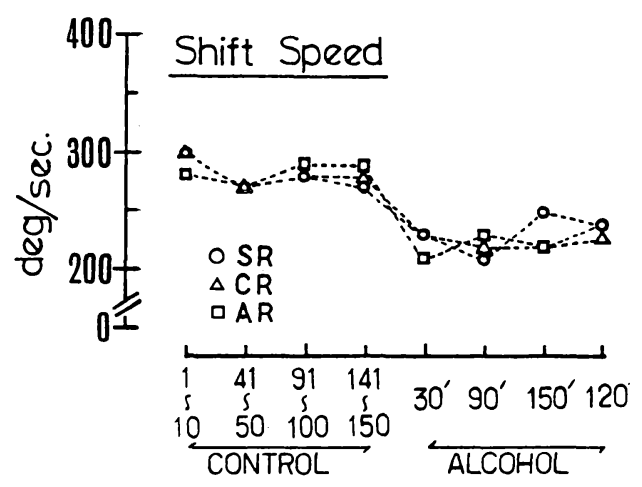

